\title{
Global competition - implications for enforcement
}

\author{
by Professor Susan Beth Farmer
}

\begin{abstract}
This article is derived from a lecture that I had the privilege to present on 24 March 2003, as part of the IALS Public Lecture series. I was fortunate to have spent the spring as an Associate Research Fellow at the IALS in connection with my role as academic director of the Pennsylvania State University Law School London Law Programme and teacher of a course in comparative competition law. My views are formed, in part, by my prior service as an Assistant Attorney General in the Antitrust Bureau of the New York Attorney General's Office. As a point of departure, this paper proceeds from the perspective that the engines of vigorous competition promote development and provide economic and social benefits to consumers and firms and, if markets are subverted by private cartels, law enforcement is necessary to protect consumer welfare. Although this paper will deal largely with government enforcement of competition laws to protect global competition, it should be recognized that private civil actions may be an important component of competition enforcement in many jurisdictions.
\end{abstract}

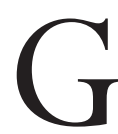
lobal competition is a particularly topical subject because, as my Penn State colleague Professor Larry Backer has written, in today's globalized society, no state and few firms can conduct their affairs without reference to the legal norms of other states. For consumers and corporations alike, much modern trade is conducted with little regard for national borders. The ease of communication, commerce and travel that facilitates international business, however, also increases the risk that anticompetitive behavior will cause harm to consumers and competition in more than one jurisdiction. Thus, modern competition lawyers must counsel their clients in an environment where business is conducted across borders and restraints of trade cause harm internationally and national competition laws can be enforced extraterritorially.

Whilst purely domestic commercial activity is plausible, its effect on the global market is arguably virtually de minimis. Since commercial activity in one jurisdiction likely affects other states, legal actors and systems must communicate effectively with each other when adopting and enforcing laws that have multi-national impact. Importantly, legislators and law enforcement officials are already cooperating and competition law is undergoing a process of consolidation and harmonization. This ongoing communication, I will argue, goes far towards alleviating problems of multiplicitous enforcement and establishing safeguards that further the benefits of global competition.

On one level, the issues raised by global competition enforcement are purely instrumental: a function of ascertaining whether are there differences in substance or procedure that matter, identifying these areas of divergence, evaluating their significance, and deciding whether and how they should they be resolved and by whom. On a nonutilitarian, non-pragmatic level, it is also important to identify the theoretical bases for any divergences among competition laws and enforcement regimes and to inquire whether such laws and enforcement priorities should be harmonized, and evaluate the justifications for harmonization.

I write from a uniquely American perspective that includes an appreciation of the federalist model of competition law enforcement that is the norm. In the United States, two federal agencies, the US Department of Justice and the Federal Trade Commission, plus the Attorneys General of the 50 states are empowered to enforce the federal competition laws, the Sherman and Clayton Acts. While the federal government has exclusive authority to prosecute criminal actions under federal law, the states are explicitly empowered by the Sherman Act to represent the natural person citizens of their states as parens patriae and to seek equitable relief and civil damages on their own behalf under federal competition law. In addition, nearly every state has its own state competition law, also enforced by the state competition agency (typically a division of the office of the state Attorney General's Office) with civil and, in most states, criminal penalties. State law is ordinarily interpreted in conformity with federal competition law but there may be substantive and procedural differences in some states.

Finally, private parties injured by anticompetitive activity may bring private civil actions under federal and most state 
laws to recover damages and injunctive relief. Parallel investigation and litigation by a federal agency and one or more state agencies plus private parties are not infrequent. These multiple governmental agencies frequently cooperate in investigations, share information, and may prosecute cases jointly, but there is no legal requirement that they do so and, from time to time, they have disagreed on the competitive effect of a particular activity, leading to different legal analyses and inconsistent legal actions. Thus, one agency may seek to prohibit conduct that another concludes is not anticompetitive, and the US Supreme Court has explicitly held that states are not pre-empted from bringing these competition cases.

I would argue that there is real value, but also a real cost, in the existence of multiple enforcement agencies because, if one agency fails to take action, another may do so. The reasons for acting, or failing to act, are diverse and reflect the value and costs of multiple enforcers. First, an agency may act, challenging a practice or refusing to challenge it, for reasons that have nothing to do with competition, for example, to protect national firms or local employees rather than competition. Second, the goals of the competition law on one jurisdiction may be inconsistent with the norms underlying the law of another jurisdiction, for example, one law may be based on economic efficiency goals and another may seek to further social and political goals. Third, competition enforcement agencies, representing their sovereign interests, are entitled, indeed mandated, to pursue their own interpretation of the public interest. Finally, competition law has evolved as economic learning develops and there may be a range of correct answers to many issues of competition law interpretation.

\section{PROBLEMS OF MONOPOLY AND RESTRAINT OF TRADE}

The problems of monopoly and restraints of trade are ancient issues. In England, the earliest reported case on restrictive covenants, which are effectively agreements not to compete, Dyer's case, was decided in 1414. The most famous common law case for American students of competition law, Mitchell ${ }_{v}$ Reynolds, was decided in 1711, and the Statute of Monopolies, dating to 1844 , is nearly as ancient. The common law reasoning of these and other early cases influenced the development of United States antitrust law, including the 1899 Addyston Pipe case written by then Judge William Howard Taft in his role as a judge on the Sixth Circuit Court of Appeals. Judge Taft's reasoning, distinguishing ancillary restraints of trade from direct restraints, has found its way into the modern jurisprudence of the United States Supreme Court so, in one sense, "globalization" and harmonization have been a feature of competition law for generations. The increasing number of state competition laws and transnational conduct of business, however, makes the issue one of more than merely historical interest.
Today, at least 90 states, including both first world and developing countries, have enacted competition laws and many of them have active enforcement regimes. As this journal's readership is well aware, accession to the European Union requires applicants to meet various criteria including adoption of a competition law that is not inconsistent with the EU competition laws, currently found in Articles 81 and 82 (formerly Arts 85 and 86). A draft competition law is currently under consideration by the People's Republic of China. In addition to this vast array of state competition enforcement agencies, there are many international bodies with an interest and expertise in competition law matters, including the World Trade Organization, the OECD, and the International Competition Network (ICN). More than half of the WTO member countries have adopted some version of a competition or anti-monopoly law and the WTO members have established a working group on competition laws and enforcement.

Although a vast number of nations have enacted competition laws, most were adopted recently, within the past several decades. Japan and Germany, for example, lacked competition laws until the post-World War II era. European Union competition laws date from the founding of the union, then the European Economic Community, with the Treaty of Rome in 1957. The United States antitrust laws, including the Sherman Act adopted in 1890, have the longest history of sustained government enforcement and the most thorough doctrinal and theoretical development through common law case law. The list of jurisdictions that have adopted modern competition laws includes nations from Albania to Zambia, including all the EU member states, Australia, Brazil, Canada, Indonesia, Israel, Japan, Korea, Mexico, New Zealand, Pakistan, Peru, Russia, South Africa, Thailand, Turkey, and Venezuela, among numerous others.

\section{SIMILARITIES BETWEEN NATIONAL COMPETITION LAWS}

Although there are some substantive and procedural differences among the existing competition statutes, most have important features in common. Most national competition laws broadly prohibit horizontal cartels, such as agreements among competitors to fix prices, rig bids or allocate markets. Most also condemn certain vertical agreements between firms at different levels of the chain of distribution, particularly those agreements that fix resale prices or require purchasers to buy one product in order to purchase another, so-called "tying arrangements," or otherwise unreasonably restrain competition. Most jurisdictions prohibit single firms from amassing too large a share of a market and abusing their market power, in provisions variously termed "abuse of a dominant position" or "anti-monopolization" laws. Finally, nearly half of all jurisdictions have adopted laws regulating mergers and requiring merging firms to notify the 
enforcement agency, provide information, and receive approval before consummating the merger.

Although substantive prohibitions are therefore largely congruent, there are important procedural differences, making counselling and compliance difficult and costly. These inconsistencies are particularly troubling in the area of merger review, in which firms may be required to seek approval in every jurisdiction in which they do business and the timetables for review and particular information required to be produced may vary. Another important area of divergence is in the level of expertise and commitment to enforcement by government competition agencies.

In the United Kingdom, the Office of Fair Trading is the lead competition enforcement agency. The OFT Board was created on 1 April, 2003, and is currently chaired by John Vickers and includes an executive director and five other members. Charged with enforcing the Competition Act, the OFT articulates its mission as halting cartels and other anti-competitive arrangements, investigating and challenging firms found to be abusing a dominant market position, and cooperating with the European Commission Competition Directorate and other international competition authorities. The Competition Commission, a separate independent body, is charged with investigating monopolies, mergers and economic regulation of utilities referred by UK competition authorities. This body was established by the Competition Act of 1998, superseding the Monopolies and Mergers Commission. Chaired by Sir Derek Morris and two deputy chairs, the 40-member council members are appointed by the Secretary of State for Trade and Industry. The Commission comprises a "Reporting Side" to investigate monopolies, mergers and other matters referred to it and an "Appeals Tribunals" to consider appeals of decisions made by the Office of Fair Trading and other economic regulatory authorities.

\section{SHOULD A UNIFORM INTERNATIONAL COMPETITION LAW BE CREATED?}

The multiplicity of competition laws and the potential for conflicts may increase the costs of doing business for firms competing internationally without a corresponding benefit for consumers. These costs include the time and expense of ascertaining the competition laws to which they are subject, frequent training programs to educate their employees in the field to comply with the legal requirements, and the legal expenses of compliance with the substantive provisions. Indeed, firms may fear that they may be faced contradictory substantive or procedural requirements of some statutes and therefore decline to enter particular markets in states with new or unfamiliar competition laws. These costs hamper firms in pursuing their legitimate business objectives and deny consumers the economic benefits of their presence in the market. Therefore, in consideration of the economic costs of multiple competition laws and enforcement regimes, one might reasonably inquire whether 90 distinct competition laws are necessary to protect consumers from anticompetitive conspiracies.

Uniformity could be obtained by adoption of a supranational competition law enforced by a supra-national agency such as the WTO. Alternatively, a single, uniform competition law could be adopted superseding the 90 individual national statutes currently on the books. However, before advocating uniformity in either form, specific differences between individual competition laws and their justifications must be examined.

A fundamental objection to a uniform international competition law is that the states which have adopted these laws differ fundamentally. The American Bar Association Sections of Antitrust Law and International Law and Practice, in a January 2000 Report on the Internationalization of Competition Law Rules, describes seven distinct national models among the states that have adopted competition laws. The national model inevitably influences the particular substantive provisions and procedures of the laws, as well as the enforcement priorities of the government agencies charged with enforcing them. These national models include::

1. The Capitalist Model (the US), which seeks to prevent only those private practices that interfere with the competitive process and reduce economic welfare;

2. The Social Market Model (Germany), which seeks to limit political as well as economic power and is more protective of smaller market players;

3. The European Union Model, which is designed to enhance the creation of a common market, is more regulatory than the capitalist model, and also reflects a greater concern for the welfare of market actors;

4. Industrial Policy with Competition (Japan), which has been characterized by strong government involvement in organizing a tight-knit domestic economy and minimal enforcement of competition law;

5. The Statist Model (China), which involves pervasive government involvement in the economy with little, if any, competition laws;

6. Restrictive Practices Law (Less Developed Countries), which principally prohibit abusive or exclusionary conduct by large, multi-national corporations; and

7. The Free-Market, No-Competition Law Model (Hong Kong and Singapore), which relies solely on market forces.

Given the different social and legal norms of these jurisdictions, it is inevitable that the various competition laws have different underlying goals. At least four different goals may be identified:

- competition,

- social \& political values,

- economic efficiency,

- elimination of barriers to free movement of goods 
The goal of favoring competition for its own sake and for the social benefits competition confers is perhaps best exemplified in Judge Learned Hand's 1945 opinion finding that Alcoa Aluminium Co. violated section 2 of the Sherman Act, which prohibits monopolization. Rejecting Alcoa's argument that it did not extract more than fair profits, the court stated that:

"The Act has wider purposes. Indeed, even though we disregard all but economic considerations, it would by no means follow that such concentration of producing power is to be desired, when it has not been used extortionately. Many people believe that possession of unchallenged economic power deadens initiative, discourages thrift and depresses energy; that immunity from competition is a narcotic, and rivalry is a stimulant to industrial progress; that the spur of constant stress is necessary to counteract an inevitable disposition to let well enough alone."

In 1894, the House of Lords articulated another justification for competition laws: the public interest. In Nordenfelt $v$ Maxim Nordenfelt Guns \& Ammunition Co (App. Cas. 535, 565), the House of Lords declared that:

“The public have an interest in every person's carrying on his trade freely: so has the individual. All interference with individual liberty of action in trading, and all restraints of trade themselves, if there is nothing more, are contrary to public policy, and therefore void."

Early American courts went even further, with Justice Peckham declaring in the 1987 case of United States v TransMissouri Freight Ass'n. that the agreements at issue:

"may even temporarily, or perhaps permanently, reduce the price of the article traded in or manufactured, by reducing the expense inseparable from the running of many different companies for the same purpose. Trade or commerce under those circumstances may nevertheless be badly and unfortunately restrained by driving out of business the small dealers and worthy men whose lives have been spend therein, and who might be unable to readjust themselves to their altered surroundings. Mere reduction in the price of the commodity dealt in might be dearly paid for by the ruin of such a class ..."

There is evidence in the legislative history of the Sherman Act that the members of the 1890 Congress were concerned about the social and political costs of monopolies and cartels and that they sought to promote local control of business, prevent the transfer of wealth from consumers to firms with market power and protect and "small dealers and worthy men" from too intense competition from large corporations. These justifications for competition laws and enforcement have been largely rejected by modern American courts and commentators, but they may form the basis for competition laws and policy adopted by other states.

A February 2003 Report of the American Bar Association, Section of Antitrust Law, declares that promotion of economic efficiency should be recognized and effectuated as the fundamental goal of competition laws. Any additional goals, according to the Report, should be achieved through other statutes explicitly drafted to override the competition policies in particular cases and should be applied transparently so that it is clear that they do not further competition policies but other non-economic goals. Example of such free-standing rules include limitations on media concentration or protection of domestic industry for non-economic strategic considerations.

\section{EUROPEAN UNION COMPETITION LAWS}

The European Union's competition laws were designed to preserve peace by binding together the six original EEC states in a common market. Since private cartels, as well as competing national economic and trade policies, could frustrate that overriding goal, the Treaty of Rome included competition Articles prohibiting private restrictive agreements and abuse of dominant market positions. Although the competition Articles of the Treaty are substantially similar in language to sections one and two of the Sherman Act, they have the additional goal of breaking barriers to trade among Member States, which may mandate different interpretations of what activity constitutes a restrictive agreement or abuse of a dominant position. Thus, Article 81 provides, in part:

The following shall be prohibited as incompatible with the common market: all agreements between undertakings, decisions by associations of undertakings and concerted practices which may affect trade between Member States and which have as their object or effect the prevention, restriction or distortion of competition within the common market, and in particular those which:

(a) directly or indirectly fix purchase or selling prices or any other trading conditions;

(b) limit or control production, markets, technical development, or investment;

(c) share markets or sources of supply;

(d) apply dissimilar conditions to equivalent transactions with other trading parties, thereby placing them at a competitive disadvantage;

Similarly, Article 82 provides:

Any abuse by one or more undertakings of a dominant position within the common market or in a substantial part of it shall be prohibited as incompatible with the common market insofar as it may affect trade between Member States.

Such abuse may, in particular, consist in:

(a) directly or indirectly imposing unfair purchase or selling prices or other unfair trading conditions;

(b) limiting production, markets or technical development to the prejudice of consumers;

(c) applying dissimilar conditions to equivalent transactions with other trading parties, thereby placing them at a competitive disadvantage; 
(d) making the conclusion of contracts subject to acceptance by the other parties of supplementary obligations which, by their nature or according to commercial usage, have no connection with the subject of such contracts.

In addition to the differences found in the underlying goals of various national competition laws, there are other real differences, both substantive and procedural, which subject multinational firms to potentially conflicting rules of law. These real divergences arise from, among other factors:

- different substantive standards, in which a particular activity is prohibited in one jurisdiction and not in another;

- different remedies, including, for example, the possibility of criminal prosecution in the United States but not the European Union for the same activity, the existence of a private right of action brought by persons injured by competition violations, and differences in the measure of civil damages ranging from mandatory treble damages in the United States to actual damages;

- procedural differences, especially with respect to deadlines for notification of proposed mergers;

- varying expertise and commitment to enforcement by the administrative agency charged with enforcing the law;

- finally, enforcement agencies may disagree on the correct interpretation of the facts of a case or the legal interpretation of their individual enabling statutes. Courts and agencies may interpret their statutory mandate in different fashions, especially if the statutory language is as broad and vague as sections one and two of the Sherman Act, which simply prohibit contracts, combinations and conspiracies "in restraint of trade" and "monopolization" respectively.

(See the January 2000 ABA Report for a fuller discussion of these considerations.)

\section{CONSEQUENCES OF EXTRATERRITORIAL ENFORCEMENT}

It must be acknowledged that there are potential costs of divergent competition goals, statutory language, and duplicitous application. In particular, extraterritorial criminal enforcement may subject non-citizen individuals and corporations to high fines and incarceration even if their native competition law lacks such draconian penalties. In a recent speech, the Director of Criminal Enforcement of the US Justice Department Antitrust Division disclosed that approximately 40 grand juries were investigating suspected international competition violations whose subjects were located in more than 25 countries. The priority the United States enforcement agency gives to criminal prosecution is reflected in the official's report that more than \$2 billion in fines were imposed since 1997 and more than 10,000 total days of incarceration were ordered during the previous year alone.

Significantly, since 1998, more than half of corporate criminal defendants were foreign-based firms. Extraterriorial civil and criminal competition enforcement exposes firms and corporate officers and agents to liability in numerous jurisdictions. ("A Summary Overview of the Antitrust Division's Criminal Enforcement Program”, by Director of Criminal Enforcement Antitrust Division US Department of Justice Scott D Hammond, 23 January, 2003). Moreover, even if government competition agencies cooperate with each other, private actions, not controlled by the state, expose firms and individuals to further civil liability. Although private civil actions do not carry the stigma of criminal conviction or incarceration, multiple damages mandated by some competition laws may exceed criminal fines. Finally, there is the real cost of information and compliance with competition laws in multiple jurisdictions.

Even though most substantive provisions of competition laws are largely consistent, there have been examples of conflicts. These conflicts are most problematic in major merger cases because the costs of divergence are most acute; these high profile deals involve large sums of money and severe pressure to obtain prompt governmental approval. When there is conflict, with one state's competition agency approving a proposed merger and another challenging it, there may be claims that one or another agency applied improper standards, such as nationalist protectionism, to prohibit or approve a particular merger.

Happily, these conflicts have been few - in the more than 10 years since adoption of the EU Merger Regulation, there have been only two serious conflicts between EU and US competition agencies over potential mergers. In 1996, Boeing Co and McDonnell Douglas Corp notified the EU and US competition agencies of their agreement to merge. The US Federal Trade Commission approved the merger, over one dissent, within six months of the initial notification. The European Commission ultimately approved the merger, contingent on the firms' agreement to certain undertakings, after initially recommending that it be prohibited and considerable public controversy. The second conflict was the proposed merger of General Electric and Honeywell, announced in October 2000. Again, after investigation, the United States Justice Department, choose not to challenge the proposed $\$ 45$ billion acquisition, while the EU Commission, after investigation and negotiation, choose to prohibit the transaction. The merger agreement was terminated but the case is pending before the European Court of Justice.

Again, the Commission's decision was the subject of strenuous criticism in the American press, including comments by private and government officials that threatened to upset the collegial working relationship that the two agencies had developed over many years. Despite the costs to private parties and the continuing cooperation among enforcement officials of disagreement, it must be stressed that actual conflicts are rare compared to the total number of proposed mergers reviewed. The EU 
Commissioner for Competition Policy, Professor Mario Monti, has pointed out that, of all the proposed mergers reviewed by the Commission since the adoption of the Merger Regulation, only 18 , or approximately $1 \%$ of all notifications, have been prohibited and only $6 \%$ were conditioned on additional undertakings by the parties (in a speech before the IBA on 7 November 2002).

There are other potential substantive divergences between various national competition laws despite broad general agreement on the fundamentals of competition law. In particular, some jurisdictions, including the United States, treat non-price vertical restraints of trade as largely pro-competitive or competitively neutral in most cases. By contrast, the European Union competition law tends to be more sceptical of the potential pro-competitive effects of vertical agreements and is more likely to condemn agreements than comparable United States courts in comparable cases.

Similarly, with respect to substantive merger and monopoly standards, the EU competition law prohibits the "abuse of a dominant position" while the United States prohibits monopolization and mergers that may tend to create a monopoly. The difference in statutory language arguably reflects some divergences in substantive interpretation, with European authorities, on the whole, more likely to prohibit a practice based on bundling and portfolio effects, whilst American merger analysis tends to consider primarily the direct rather than indirect effects, in the view of some commentators. To reiterate, however, the relevant enforcers have stated that they believe that the areas of divergence are small and, in actual practice, serious disagreement and conflicting decisions have been few.

For all of the foregoing reasons, one can characterize the world-wide state of competition law as follows:

First, a large number of jurisdictions, more than 90 at current count, and including both first-world and developing nations, have enacted competition laws since the middle of the twentieth century, with the majority having been adopted even more recently. This trend is likely to continue for a variety of reasons, including the influence of multi-national organizations, which recommend or mandate such laws to potential member states;

Second, competition laws tend to share many common features, generally condemning the same hard-core restraints of trade, however, there are non-trivial differences in substantive doctrine and procedure among jurisdictions. Moreover, the underlying jurisprudential basis and goals of competition laws may vary significantly depending on jurisdiction, including such diverse justifications as economic efficiency, furthering social and political goals, achieving a unified common market, and other goals;

Finally, there are both costs and benefits of the existence of a multiplicity of competition laws in a world characterized by increasing global competition. The potential costs include the cost to firms of information and compliance with multiple competition regimes, whether or not the legal requirements are inconsistent. The potential benefits include the sovereign right of individual states to effectuate their individual competition-based goals, the likelihood of different competitive effects of the same activity in different jurisdictions, and the protection for consumers found in duplication of resources, e.g. even if one state fails to proceed against anticompetitive activity, others are available to enforce their own law and challenge the harmful activity.

\section{CONCLUSION}

I conclude that, on the whole, the benefits of multiple competition laws and enforcement regimes outweigh the costs. However, the potential costs are significant and should be minimized to the greatest extent possible to facilitate global competition while protecting consumers and competition from multinational cartels, restrictive agreements, and monopolies. My final goal for this short lecture, then, is to articulate a standard to evaluate whether a particular resolution to inconsistent global enforcement is recommended. Any such model for minimizing conflicts must further the values of competition law and enforcement and reserve sufficient discretion for individual sovereign states to effectuate their own legitimate competitive goals and evaluate the effect of cartels on their own consumers and competitive processes.

I would argue that the characteristics of such a model system include the following: competition law or laws, and their enforcement regimes, should be predictable, transparent, efficient, non-discriminatory in application, and legitimate or credible. There are three possible approaches to achieving these goals: preemption of state competition laws in favor of enforcement of a supra-national standard by a supra-national entity, formal convergence, eg. adoption and enforcement of a uniform competition law by individual states, and soft harmonization or consultation among individual states with the goal of agreement on important substantive and procedural standards where conflicts are likely.

The supra-national enforcement agency model fails to meet the criteria for minimizing costs and maximizing benefits of individual state competition laws and enforcement regimes. While such an agency could be efficient in that it offers a single point of review and enforcement rather than a multiplicity of law enforcement actors, it must also guarantee that it would be even-handed in applying the law and possess international legitimacy. The current leading model for such an agency is the WTO, and, although there are 145 WTO member states, that organization has not achieved a reputation for transparency necessary to enforce laws that so directly affect individual consumers and local businesses. Further, the constitutional courts of individual states are more likely to possess the legitimacy and credibility to enforce competition laws extra-territorily than WTO-like dispute settlement bodies. 
Finally, to eliminate the risk of multiplicitous lawsuits, any supra-national scheme would have to pre-empt not only state enforcement but also any private remedies that exist under state competition law. At this time, a supranational competition scheme does not meet the criteria for maximizing benefits and minimizing costs of multiple competition laws and enforcement regimes.

A second possible solution is formal convergence or adoption by sovereign states of a uniform competition statute. The best example of this model is the European Union, which requires enactment of a competition law not inconsistent with Articles 82 and 82 as a condition of accession. This model achieves uniformity of law and, possibly, requires the individual states to adopt the underlying goals of the statute. Mere formal convergence, however, does not necessarily require all states adopting the model law to apply it in a non-discriminatory fashion to domestic and foreign actors. Moreover, formal convergence also fails the requirements of efficiency and predictability since the individual states will remain free to enforce their own, albeit identical, laws, according to their own discretion.

In my view, the model that provides the most promise is consultative, potentially leading to soft harmonization of substance and procedure. The best example of a consultative process at work is the new International Competition Network, formed in 2001, a voluntary "informal network of antitrust agencies ... that will address antitrust enforcement and policy issues of common interest and formulate proposals for procedural and substantive convergence through a results-oriented agenda and structure" (see www.internationalcompetitionnetwork.org). Membership is limited to the national or multi-national competition agency(ies) responsible for competition enforcement and currently includes more than 65 jurisdictions.

Significantly, the group does not seek to create a single multi-national enforcement body or to mandate adoption of a particular uniform law. To the contrary, its goals are modest, but more likely to satisfy the requirements for balancing the benefits and costs of global competition enforcement. These goals include seeking agreement on core principles of competition law, specifically those hard core offenses that are most harmful to competition and consumers, benchmarking or establishment of guidelines of best practices for use by individual jurisdictions, harmonization of procedures that potentially cause the most difficulties for firms such as timetables for merger investigations, and adoption of protocols for individual jurisdictions to share information, documents, and expertise in individual investigations or more generally.

The network seeks to ensure its legitimacy and credibility by limiting membership to governmental agencies and reserving a purely advisory role for private firms, which are invited to comment but do not have a policy-making role. The transparency criteria is promoted by this openness to non-governmental actors, and the goal would be further advanced if the organization sought to broaden the set of advisors to include representatives of consumers as well as firms through various NGO civil society organizations. The network's "focus will be on improving world-wide cooperation and on enhancing convergence through focussed dialogue." Thus, by promoting harmonization of competition law substance, process, and interpretation, the network is likely to enhance the predictability of competition enforcement by its member jurisdictions.

For all of the reasons discussed above, I conclude that global competition has serious implications for competition enforcement. The current 90 jurisdictions that have adopted and are enforcing their own competition laws offer the benefits of competition for their citizens and firms doing business in these states. Vigorous competition is a powerful route to improving the economic and social condition of citizens by allowing them to participate in a fair market economy. However, since these numerous competition laws may have differing underlying goals, substantive standards, and procedures, there are inefficiencies and costs to firms seeking to compete in multiple jurisdictions.

In order to minimize the costs and maximize the benefits of multiple competition enforcement, reform should seek predictability, transparency, efficiency, legitimacy and credibility, and non-discriminatory enforcement. At this time, a supra-national enforcement agency that pre-empts state competition laws and enforcement not is not likely to achieve these goals. Whilst substantive uniformity on core issues is plausible, agreement on non-core issues and underlying norms is unlikely to be achieved. Moreover, differences in enforcement priorities and expertise make a uniform law an unappealing option. Voluntary cooperation, consultation and soft harmonization among state competition agencies offers the most promise. Harmonization, especially if the consultative process includes representatives of diverse interests including consumers, is efficient, transparent and credible. To the extent that agreement on core principles and processes is achieved, enforcement will be more predictable and fair.

Promoting global competition is critically important and should be of major interest to enforcement agencies worldwide. While respect for diversity of goals and methods of achieving the benefits of competition is important, cooperation among enforcement agencies is also crucial to minimize the costs for legitimate firms of compliance with multiple systems. Finally, successful cooperation is more likely to be found in consultative process like the ICN and does not require a single global competition law or sole enforcer. 슬

\section{Susan Beth Farmer}

Professor of Law, Dickinson School of Law, Pennsylvania State University 